\title{
Aspects of Political Leadership Relevant to Voters' Choice and Preferences
}

\author{
Khairul Azmi Mohamad ${ }^{1} \&$ Nooraini Othman ${ }^{1}$ \\ ${ }^{1}$ Perdana Centre, Razak Faculty of Technology \& Informatics, Universiti Teknologi Malaysia, Malaysia \\ Correspondence: Nooraini Othman, Perdana Centre, Razak Faculty of Technology \& Informatics, Universiti \\ Teknologi Malaysia, Jalan Sultan Yahya, 54100 Kuala Lumpur, Malaysia. Tel: 60-3-2180-5157. E-mail: p- \\ noraini@utm.my
}

Received: May 18, 2020

doi:10.5539/jpl.v13n4p11
Accepted: August 31, $2020 \quad$ Online Published: October 13, 2020

URL: https://doi.org/10.5539/jpl.v13n4p11

\begin{abstract}
This paper intends to analyse political leadership from the perspective of political behaviour of political leaders. There must be a reason for voters to decide which election candidate to vote. Political leadership as contextually described represent some of the most important elements for voters to decide whether or not a particular leader should be elected as Member of Parliament or State Legislative Assemblies in Malaysia. There are five aspects of political leadership forming leadership characters relevant to voters' choice and preferences in any given election. They are loyalty, integrity, competency, commitment and resilience. The absence of these characters could render a particular candidacy a fatal. These five characters could be regarded as principle centred of a leader and in the same time the main features that would contribute to the success of an elected political leader. It is not only words best spoken by the candidate but also the campaigner's success in highlighting these characters to the voters that would open their eyes to vote the best candidate. In some cases, traditionally, at some constituency votes are given to the parties that have been traditionally representing the constituency. To a certain extent it is called the party's 'traditional seat'. Now, voters do not only look to a party or the so-called 'traditional seat' context. Today voters give high regards to who the candidates are and what are the qualities the candidates have.
\end{abstract}

Keywords: political leadership, political psychology, voter's behaviour, Malaysian politics

\section{Introduction}

The issue of political leadership and the desire to witness good leader in action have been the aspiration of many nationals. A good leader demonstrates some significant attributes and becomes the possessor of desirable qualities. A leader must understand the leadership role to be performed. In performing such role, a leader is doing it without fear or favour to the interest of some elites or conflicting interests.

Political leadership attracts support and vote. It is like the first impression people have towards a person and perhaps collectively as a party. It relates to matters that voters would want to see in a leader. A weak leader does not deserve a vote. A corrupt leader should not stand re-elected. People generally want to have a leader who is honest, full of integrity, able to sustain challenges, possess high skill of diplomacy, charismatic, far sighted, visionary, intelligent, passionate in works, reliable, disciplined and courageous. In essence, it relates to leadership personality, behaviour and character.

Similarly, in the context of a party, when the party provides what it takes to lead a country, naturally the party would win the support of the people and gets voted in. People would support the party that reflect the leadership integrity, honest and loyal to the struggle, putting people above all, be the one that serves the nation and not prone to corruption.

In so far as the Third World Nations continue to elect, select or appoint ineffective and selfish leaders, the issue of bad governance and its associated problems of political instability, social malaise, corruption, lack of accountability and transparency, and the respect for the rule of law will persist in the developing nations (Udago, 2008).

Malaysia needs strong leaders who can propel this country to a greater height. The country needs a visionary leader who can set the country's direction, an exemplary leader who can be emulated by its people, an intellectual leader who will guide the people to think and direct them to plan on the next course and shape of the country. The way 
forward looks ambitious but it has to start somewhere within the political leadership fraternity.

\section{Methodology}

This work is based on thematic literatural studies. It is an early approach to look at political leadership from the context of leadership characteristics. Five characteristics, namely loyalty, integrity, competency, commitment and resilience are chosen to reflect such leadership. This work argues that these are some of the important characteristics voters would look at a particular candidate before deciding to cast their votes in a given election.

\section{Political Leadership Psychology}

Christof Miska and Mark E. Mendenhall in their work Responsible Leadership: A Mapping of Extant Research and Future Directions spoke about responsible leadership as their focus of analysis. Their works expanded leadership studies further, encompassing theoretical and conceptual potential, involving numerous studies across different levels of analysis, and open to various methodological approaches (Miska and Mendenhall, 2018).

The field of psychology has the capability of responding intellectually and scientifically to the study of politics. The science of psychology has been utilised by the political scientists to look at their subject matter in order to understand political behaviour from this scientific perspective. Charles Merriam observed the ability of the psychologists to develop the method of measuring human personality is beneficial to develop the study of political personality and methodology for the realm of political psychology in a systematic manner. The political scientists will be struggling in difficulty to understand human nature without knowing this scientific method (Merriam, 1921).

Many students of politics have been calling for the development of political psychology. They acknowledged the efforts of the past generation for their strides in the study of psychology. Lord James Bryce in his last work on Modern Democracies unreservedly said that "psychology is the basis of government" and politics - "accordingly has its roots in psychology, the study (in their actuality) of the mental habits and vocational proclivities of mankind" (Merriam, 1924).

\section{Traditional Seat}

In the context of Malaysia, the notion of 'traditional seat' connotes the seats that are usually won and retained by a particular party in the election. The voters in such constituencies have more or less decided to give their votes to their 'traditionally' favoured political party. If Barisan Nasional Party $(\mathrm{BN})$ traditionally wins the seat, in the coming election it can be anticipated that BN will retain the seat. Sometimes the candidate may not be the best personality to contest in such constituency. They are doing it for their "traditional loyalty" to the party.

Today, 'party matters' is not the only consideration by the voters. Voters have the tendency of looking at who the candidates are? Are they fit to lead or to receive the voters' mandate? This is due to the democratic maturity in Malaysia. Voters have and know their expectations towards an election candidate. They would prefer to give their votes to the candidates who fulfil their aspiration. Therefore, it is best for any party to give due regards to the necessary leadership requirements as per the request of the voters instead of fielding the party's own candidate who lacks the required leadership qualities.

\section{Political Leadership}

Leadership studies are much dominated within the realm of business and organisational fields. Hartley and Benington argued that political leadership is critical in its own right (2011). Political leadership cannot be divorced from the democratic system of government. Democratic government owes its legitimacy from the people. The people who voted the leaders to manage the affairs of the nation are the stakeholders of the democratic government. The people are at the centre of the affairs. In essence, the government has to be responsible to the people.

Political leaders made many important decisions. Their decisions involve and include social, economic, legal, safety and educational matters. Sometimes it deals with the fate of the nation and even the fate of one's life. Their public decisions are wide ranging and they are accordingly accountable for what they have decided.

The study of political leadership is, inevitably, not only about ideas (theories, concepts, evidence) but also about what political leadership ideally ought to be like. In other words, it is both analytical and normative. Political leadership is freighted with many values about the just society and the public good, about the relative power and responsibility of politicians vis-à-vis the people who elect them, about what Plato call wisdom and virtue in political life, and what Aristotle describes as prudence, as well as other values (Hartley and Benington, 2011).

Kevin Morrel and Jean Hartley in 2006 made a research entitled A Model of Political Leadership, quoted Chambers Dictionary, 1993 in defining political leaders. Political leaders have been defined as "democratically elected 
representatives who are vulnerable to deselection, and operate within, as well as influence a constitutional and legal framework. Their source of authority is a mandate, permission to govern according to declared policies, regarded as officially granted by an electorate." The electorate's qualification is specifically spelled-out by the Constitutional law. Every citizen with voting rights, in a defined constituency is eligible to vote. This facilitates our understanding on political leaders' legitimacy to authority.

Being different from other types of leaderships, political leaders shoulder different types of responsibilities. Their model helped readers and other researches understand a new way of looking at political leaders. Their work calls for further elaboration and theorising.

Political leadership has been witnessing a declining trend. The blame is on the politicians, political parties and extended to political institutions. Major democratic parties have been witnessing unprecedented changes. They are either not anymore leading the government or becoming part of the government with lesser grips and say (i.e. a reduced number of seats). In Europe, the strongest legendary party, Conservative is facing such trouble. Being defeated by the Labour Party in 1997, gaining some momentum, and later has to be satisfied with being a collision member of the ruling government. In essence, ruling in partnerships. The Congress party of India being replaced with BJP and closest to Malaysia, GOLKAR had also to close shop. Malaysia suffered the same fate. In the $14^{\text {th }}$ General Election in the year 2018, Barisan Nasional (BN) had to concede defeat. The result of the $14^{\text {th }}$ General Election only allowed the party to rule two states, namely the State of Perlis and Pahang, and not helming the Federal government. For the record BN has been ruling the Malaysian Federal Government since the country's Independence in the year 1957.

Demands are tremendous but before the decline, have you done enough? This is where, not only check and balance, but also overhaul is needed to bring the party back to a good shape and commands the trust and respect of the people of Malaysia. Many feel too closely for the party but just had to send a bitter antidote to be swallowed. Progress is now being seen but challenges are also overwhelming.

\section{Aspects of Political Leadership}

Politics by leadership is the distinguishing features in the role of leadership (Seligman, 1950). It is truly important to find the people or leaders who are most capable of governing. Leadership characters represent the candidates' qualities for them to be the best choice to be elected in a given election. These will be marks for their responsibility and accountability.

Understanding political leaders comes down to studying the characteristics, beliefs, and deeds of people formally occupying the top roles in political life.

Understanding political leadership through the lens of leaders takes one to the province of psychology. It rests on the idea that it matters who governs us. It entails an agent-centred view of politics and government. In other words, public debates and decisions are shaped by the views, drives, skills, and styles of individuals who occupy formal office. Comparisons of different leaders in similar circumstances show how their beliefs and practices have an impact on the lives of citizens ('t Hart and Rhodes, 2018).

Leadership is an essential feature of all government and governance: weak leadership contributes to government failures, and strong leadership is indispensable if the government is to succeed. Wise leadership secures prosperity in the long run; foolhardy leadership may bring about a catastrophe (Masciulli et. all, 2009).

As such, the present authors have identified five essential elements of leadership characters that will substantiate political leadership. They are loyalty, integrity, competency, commitment and resilience.

\subsection{Loyalty}

According to Josiah Royce loyalty is an attitude, which makes a man give himself to the active service of a cause. Djupe suggested that loyalty is a continued psychological identification and social attachment arising from involvement with a social or political institution (Djupe, 2019). Politic is about struggle to a particular cause. Some would fight for their race and religion, another for economic prosperity and educational opportunity, while some others for justice and safety. We still have people who are still fighting for their freedom and rights over their lands - to gain independence. These are not just sweet words to spark fighting spirit among the people or to motivate followership. For the political leaders who meant for their words, they deserve the support of their voters and citizens for they have loyalty to the cause.

In politics, loyalty is a mark of trust. It operates between the leaders towards his followers. In this sense the leader showed an exemplary character by motivating the followers through his conduct, by an act of sincerity and sacrifice. 
Loyalty also operates between followers to their leaders by portraying the good conduct and obedience. This reciprocity will serve to strengthen the party.

Loyalty is much needed in any struggle. Political leaders must be loyal to the cause of their people and the country.

\subsection{Integrity}

The people, in particular voters will expect their leaders to be someone trustworthy and honest. Their leaders must keep to their promises especially what was delivered during election campaigns. Voters are also expecting for their political leaders to be truthful to their words. They mean their words. Honesty and integrity have always been recognised as leadership traits. The world has been seeing enough corrupt practices among political leaders. Instead of becoming the defender of justice and people's rights, some have decided to be abusive of their power. Integrity demands political leaders to serve their people without asking for material or physical returns.

Wise leaders have long known the value of a commitment and dedication to the practice of honesty and integrity. Throughout history it has been recognized that without these two attributes leaders cannot achieve credibility (Scarnati, 1997).

By any standard, integrity stands the tallest at any yardstick. When one's integrity is impeached, his credibility is torn apart. For politicians, they must always be mindful of this high standard already being placed on them. It is the citizenry's command. To the people, those in power are their political masters. To those in power, their political master is the people. It is the people who put them up there, and the people will bring them down in the event of culpability and mishaps.

\subsection{Competency}

In the study of political behaviour, political leadership competency runs side by side with political trust. Political leadership competency becomes an important subject matter in the analysis of political system. Without competency, political leaders are not fit to be in office. In the present day political system, the demands and expectations of the citizens are greater than the yesteryears. Oratory capacity must now be coupled with the required technical capabilities.

Being politically competence may mean one thing, but delivery competency is another important aspect. A mere competence in politics will equip a leader to survive the challenges of political life as a politician. "Political competence is the ability to understand political facts and processes and to influence these with regard to one's own interests. It is the ability to judge politics and to act politically" (Reichert, 2010). That will allow political leaders to continue living being politicians. This aspect of competency would normally be of interest to their followers and political analysts. The general public will be more interested in their delivery capacity of services. How well will they serve the people and the country? That will determine their fate in the coming election.

Competency is about political leaders' ability to function and perform their duties well - satisfactorily and met the voters' expectations.

\subsection{Commitment}

Commitment is truly important to political leadership. During election campaigns, many promises were made and should be fulfilled. Commitment is closely related to integrity. It is important to understand why political leaders need to be committed. Political leaders who won the elections are legitimated with authority. Such authority empowers them to serve their constituencies. What was argued is that if we care about political commitment, it may be useful to reflect on the kind of associative practices through which political commitment is promoted and enhanced. Political commitment is driven by a critical scrutiny of the exercise of power (Ypi, 2016). Political leadership commitments mean that leaders honour their oath of office. They have the power to change and make things better. Thus, political will is much needed to effect the necessary change as required by the people and the constituencies.

Political leaders commitment is the pillar for a successful development programmes. An early World Bank study claimed that degree of country commitment was almost universally recognized as one of the main factors explaining success. The evidence on commitment is compelling, and it would be pointless to support initiatives that have little chance of success because commitment does not exist (McCourt, 2003).

Commitment represents the high degree of dedication of political leaders towards the people and country. It normally surpasses the usual or ordinary performance of duties. It has the tendencies of doing more than the normal expectations. Voters' expectations are overwhelming. 


\subsection{Resilience}

The concept of resilience essentially appeared in the natural and physical sciences migrated to the domain of social sciences and public policy in the wake of crisis and threats in many forms. In the face of the new dynamics, the necessary responds to make good of destructions, calamities, and chaos to a new orderly and pleasant lives would be sign of leadership strength. The concept of resilience originated from both physics and mathematics as it relates to the ability of a system or material to recover its shape following a displacement or disturbance. The aptitude to bounce back or firmly rising up in the midst of a challenging situation reflects resilience.

When applied to societies and organisations, resilience highlights the importance of internal capacities and capabilities as way to cope with crises.

Resilience became a cornerstone of the 2016 EU Global Strategy on Foreign and Security Policy (EUGS), which refers to building state and societal resilience among EU neighbours as one of the key strategic priorities of EU foreign policy. Defined as "the ability of states and societies to reform, thus withstanding and recovering from internal and external crisis", the use of resilience within the strategy corresponds with the current use of the term more widely (The European Partnership for Democracy - EPD, 2017).

The leaders ability to recover or stand firm amidst challenges would be the hallmark of resilience. Intellectual capabilities of leaders have to be truly paramount. They must be able to absorb and define the parameters intellectually before proposing a dynamic solution to a particular issue, usually crisis. Leaders who are not equipped with this strength may fail miserably in their lines of duties.

\section{Conclusion}

How to promote and progress effective leadership? What are some of the behavioural characteristics that effective leaders should possess? The answers are by possessing the above political leadership characters. The list is not exhaustive and can be interpreted in so many ways. The question of why not this or why not that will be an open ended debate. The least, it has to be agreed that leadership strong positive characters must be present in the body and actions of political leaders in order to allow them to helm an effective government.

This aspect of leadership behaviour is certainly one of the most important aspects in the study of political psychology. The leaders themselves must understand and positively respond to the questions why they are expected to behave with full loyalty - to the oath of office, to the people and to the country. They must also able to respond positively why they are expected to behave with full of integrity. Political leaders should equally able to respond positively why they must behave with full of competency in the midst of their executive duties. The same goes with commitment and resilience. Challenges are always expected. Working with full diligence and ability to face challenges as well as sailing in murky waters would be important criteria for political leaders.

The political leaders ability to be mindful and consistently think of what the best for their office, people and country will be and putting them into best actions will put them at the frontline of success in their quest of becoming effective political leaders. Effective political leaders will lead to a functional government. The people will naturally care for political leaders who care for the people.

Political leadership psychology allows leaders to be more conscious of their leadership wellbeing. The motivation and rational behind their engagements and actions will be directed towards the happiness of the people. It will not be for the personal gains or interests. In the same direction, leadership behaviour guided by principles such as the five characters highlighted above will create a leader steered by principles.

\section{Acknowledgments}

Appreciation goes to the Ministry of Education Malaysia for the sponsorship under the Fundamental Research Grant Scheme (FRGS - 5F018).

\section{References}

Bryman, A., Collinson, D., Grint, K., Jackson, B., \& Uhl-Bien, M. (Eds.). (2011). The SAGE Handbook of Leadership, SAGE Publication, Los Angeles, London, New Delhi, Singapore, Washington DC.

Crozier, M. J., Huntington, S. P., \& Watanuki, J. (1975). The Crisis of Democracy: Report on the Governability of Democracies to the Trilateral Commission, New York University Press.

Djupe, P. A. (2019). Religious Brand Loyalty and Political Loyalties. Journal For The Scientific Study Of Religion. Retrieved from https://onlinelibrary.wiley.com/doi/pdf/10.1111/0021-8294.00007

Hart, P., \& Rhodes, R. A. W. (Eds.). (2018). Puzzles of Political Leadership. In The Oxford Handbook of Political Leadership. Oxford University Press. 
Hartley, J., \& Benington, J. (2011). Political Leadership. In Bryman A., Collinson D., Grint K., Jackson B., \& UhlBien M. (Eds.), The SAGE Handbook of Leadership (pp. 203-214). SAGE Publication, Los Angeles, London, New Delhi, Singapore, Washington DC.

Masciulli, J., Molchanov, M. A., \& Knight, W. A. (2009). Political Leadership in Context. In Masciulli, J., Molchanov M. A., \& Knight W. A. (Eds.), The Ashgate Research Companion to Political Leadership (pp. 327). Ashgate, United Kingdom.

McCourt, W. (2003). Political Commitment to Reform: Civil Service Reform in Swaziland. World Development, 31(6), 1015-1031. https://doi.org/10.1016/S0305-750X(03)00044-5

Merriam, C. E. (1921). The Present State of the Study of Politics. The American Political Science Review, 15(2), 173-185. https://doi.org/10.2307/1944081

Merriam, C. E. (1924). The Significance of Psychology for the Study of Politics. The American Political Science Review, 18(3), 469-488. https://doi.org/10.2307/1944171

Miska, C., \& Mendenhall, M. E. (2018). Responsible Leadership: A Mapping of Extant Research and Future Directions. Journal of Business Ethics, 148, 117-134. https://doi.org/10.1007/s10551-015-2999-0

Reichert, F. (2010). Political Competences and Political Participation: On the Role of "Objective" Political Knowledge, Political Reasoning, and Subjective Political Competence in Early Adulthood. Journal of Social Science Education, 9(4), 63-81.

Scarnati, J. T. (1997). Beyond technical competence: honesty and integrity. Career Development International, 2(1), 24-27. https://doi.org/10.1108/13620439710157452

Seligman, L. G. (1950). A Study of Political Leadership. The American Political Science Review, 44(4), 904-915. https://doi.org/10.2307/1951291

The European Partnership for Democracy (EPD), Democracy Support Factsheet, 2017.

Udogu, E. I. (2008). The Issue of Political Leadership in the Third World: What is to be Done? Journal of Third World Studies, XXV(1), 13-23.

Weber, E. T. (2010). Democratic Political Leadership. In Couto, R. (Eds.), Political and Civic Leadership: A Reference Handbook (pp. 105-110). Sage Press, Washington D.C. https://doi.org/10.4135/9781412979337.n13

Ypi, L. (2016). Political commitment and the value of partisanship. American Political Science Review, 110(3), 601-613. https://doi.org/10.1017/S0003055416000319

\section{Copyrights}

Copyright for this article is retained by the author(s), with first publication rights granted to the journal.

This is an open-access article distributed under the terms and conditions of the Creative Commons Attribution license (http://creativecommons.org/licenses/by/4.0/). 